\title{
AN IMPERATIVE NEED FOR A NEW SOCIAL ORDER IN MICROFINANCE COMMUNITY - TOWARDS USHERING IN A RESILIENT ECO-SYSTEM IN THE BATTLE AGAINST CORONA PANDEMIC
}

\author{
Ali Saleh Alshebami ${ }^{*}{ }^{\square}$ iD , Dr. V. Rengarajan 2 (iD \\ *1 Community College of Abqaiq, King Faisal University, Alahsa, 31982, Saudi Arabia \\ ${ }^{2}$ International Microfinance Consultant, India
}

DOI: https://doi.org/10.29121/granthaalayah.v8.i8.2020.986

Article Type: Research Article

Article Citation: Ali Saleh

Alshebami, and Dr. V. Rengarajan. (2020). AN IMPERATIVE NEED FOR

A NEW SOCIAL ORDER IN

MICROFINANCE COMMUNITY -

TOWARDS USHERING IN A

RESILIENT ECO-SYSTEM IN THE

BATTLE AGAINST CORONA

PANDEMIC. International Journal of

Research -GRANTHAALAYAH, 8(8), 107-123.

https://doi.org/10.29121/granthaa

layah.v8.i8.2020.986

Received Date: 04 August 2020

Accepted Date: 24 August 2020

Keywords:

Covid-19 Pandemic

Health Vulnerability

Economic Deprivation

Liquidity Crunch

Preventive Governance

Social Capital

Participatory Approach

\section{ABSTRACT}

The battle against corona does not confine to only economic resurgence by supplying microcredit to the poor clients in both demand and supply sides of microfinance sector but how to protect them from the offense of the corona in the health perspectives. In other words, imperatively it is warranted that the survival of human beings in the pandemic in the Microfinance sector merits attention on priority in the revival package. It is therefore surmised that in the process of ushering in a new social order with a resilient ecology in the Microfinance sector, there is a dilemma in awarding priority either for economic revival through the flow of microcredit for releasing financial stress or human survival with the resilient physical capability in the process of recovery from the pandemic. The study, based on secondary data, concludes that Microfinance actors need to consider that economic revival bundle should not confine with a fresh dose of microcredit alone and recovery of it collectively or individually in Microfinance sector without synchronizing a socialoriented bundle in the micro-financial package towards nurturing on health care awareness and for the obedience of obligatory preventive measures namely social distancing, Face mask, washing hands by the poor clients in the last mile. Any assumption on this issue is dangerous. The latter that guarantees the basic survival of the customers from the Corona pandemic, should precede the former one or get integrated simultaneously with it to generate a resilient ecosystem from interdisciplinary perspectives. Otherwise, another Microfinance crisis is forthcoming.

\section{INTRODUCTION}

\subsection{THE PROBLEM}

The Coronavirus Disease (COVID-19) is omnipresence and omnipotent. Causing unabated morbidity and mortality globally. Since the end game is unpredictable, it has become formidable tasks to the scientists and the researchers as well in searching a way out from the crisis. Ironically, Corona affects human beings directly and the

(C) 2020 The Author(s). This is an open access article distributed under the terms of the Creative Commons Attribution License, which permits unrestricted use, distribution, and reproduction in any medium, provided the original author and source are credited. 
viral is spread from humans to humans regardless of demographic and geography. Eventually, humanity as a whole is driven to get submerged pathetically in the pandemic challenging two scourges viz health vulnerability and simultaneously economic deprivation due to loss of livelihood. In the case of poor people, the worst impact is that the poor and the poorer in the upper layers in the poverty pyramid is ratcheted to the bottom layer to join the cohort of the poorest. Such a phenomenon of the downfall of the poor to rock bottom in the pyramid is illustratively portrayed in figure No.1 as below:

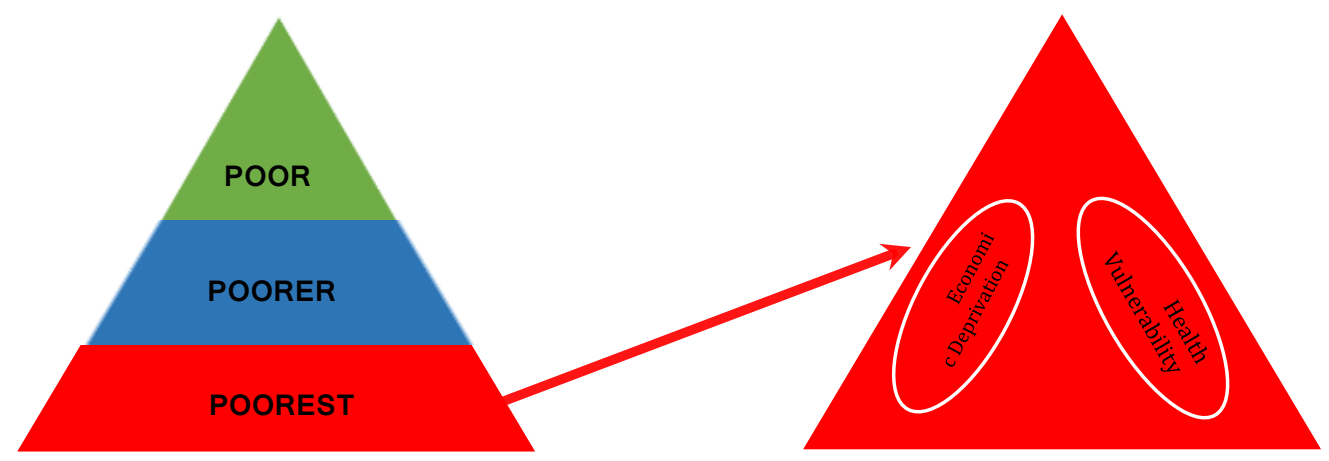

Figure 1: The Status of Microfinance Client during Corona pandemic

Source: Prepared by Researchers (2020)

By and large, this cohort in the poverty pyramid is found more in the Microfinance sector. Represented by and large self-employed and casual \& migrants laborers in micro-enterprises in the informal sector. Both economic deprivation and health vulnerability together jointly push these poor to rock bottom level $(\$ 1.90)$ in the pyramid irretrievably. During the corona pandemic, ironically the end game of crisis remains is a dubious one. Eventually, their welfare impact of COVID-19 is more on individuals, households, and their livelihoods. Aggregate shocks to economic activity can affect welfare (and well-being) at the households' livelihood of the poor segment through the following channels (world bank Brief, 2020) viz., a) Impact on labor income \& employment b) Impact on non-labor income (remittances form migrants) c) direct impact on consumption ( (food \& medicine) d) service disruption ( welfare programs related to feeding nutritious food, in school, health care services, etc,).

Ironically, this group of humanity suffers the worst in terms of both healthy vulnerability and economic deprivation despite the provision of free food grains through the Public Distribution System (PDS) and of cash assistance through Direct Benefit Transfer (DBT) to this target group as in the case of India. Reportedly as of May, about 41 Crore people have received financial assistance of Rs.52608 Crore under the Pradhan Mantri Garib Kalyanyojana Package (Reddy, 2020).

Even the minimalist approach also becomes questionable in the context of prevailing uncertainty on the end game of the corona pandemic. This sordid phenomenon drives home for designing succor that meets the multiple demands of the deeply deprived poor people in the present crisis, Otherwise sequestered succor either financial assistance in terms of free money or low-cost micro-credit with a moratorium or non-financial one like consumption goods is certainly inadequate to regain a resilient ecosystem in the economy.

\section{THE DILEMMA- ECONOMIC RESURGENCE OR HUMAN SURVIVAL}

This unabated unsavory scenario, impacted by the corona pandemic and subsequent implementation of various lockdown measures to prevent the corona spread among humanity, has immensely paralyzed the microfinance sector in terms of heavily indebted poor due to economic loss from the income-generating livelihood activities in the demand side. This phenomenon has become the causative factor attributed to affecting the financial health of Microfinance Institutions (MFIs) in the supply front. The crux of the problem in the battle against corona does not confine to the one related economic resurgence over fresh pumping of microcredit to the poor clients in both demand and supply sides of Microfinance sector but how to guard the poor clients given level of literacy from the onslaught of the corona from health perspectives. In other words, imperatively it is warranted that the survival of the poor clients of the pandemic inflicted Microfinance sector merits attention on priority in the revival package in any nation. It is therefore surmised that in the process of ushering in a resilient ecology in the Microfinance sector, there is a 
dilemma in awarding priority either for economic revival through the flow of microcredit for releasing financial stress or for human survival with the resilient physical capability in the process of recovery from the pandemic.

Further, while prevailing palatable scenario as portrayed above, the ongoing search for a panacea in terms of various curative measures to arrest the crisis causes greater concern. At the same time, violation of preventive norms in the public fuels the rate of spared of virus indicating a lack of accountability of the people both in urban and rural areas equally. The latter problem is more concerned with the individual attitude and behavior towards strict adherence to the preventive norms at Microfinance client level for the benefit of humanity as a whole. World Health Organization's warning signal indicates that "Nobody is safe until everybody is safe". Given the liberty and freedom for personal behavior and cultural diversity in the demographic scenario, how to disseminate this vital message and ensure adoption for saving humanity as a whole in the last mile from the Corona pandemic? And also how to make the horse drink the water after taking to the pond? An investigation on this issue demands a better appreciation on societal relations between the human being and the pandemic like corona from interdisciplinary perspectives

\section{SIGNIFICANCE OF SOCIETAL RELATIONS}

Contextually the perspective of the paper is to highlight the need to perceive more cognitively the microfinance target group as most vulnerable human beings who requires immediately a safety net for challenging the Corona attack from health outlook for their survival and any other economic support through micro-credit should follow not necessarily as instantaneous succor. Any disorder in the above model of approach would do more harm than do well. Therefore, as a pioneering attempt has been attempted in the paper focusing purposely on the role of two prime factors viz., societal relations and human behavior particularly from the perspectives of poor clients of the microfinance industry. It is surmised that such an interdisciplinary study covering human behavior, would help towards sustaining the greater emotional resilience in the battle against the considerable odds of COVID-19 which is a very crucial exigency contextually more particularly in MF sector serving poor clients.

\section{THE OBJECTIVES OF THE PAPER}

As against the premise, the objectives of the paper is to understand the challenges that Microfinance industry facing during the pandemic in the supply side and the dynamics of social relations of the poor people in the said bio war in the demand side and suggest a new social order towards ushering in a resilient ecosystem in the domain of Microfinance.

\section{METHODOLOGY}

The current study is grounded on secondary data collected from the literature review on the status of Microfinance shared by MFIs and their network association /organizations and on the various approaches for the participatory health care system experimented and monitored by World Health Organization (WHO) and other research institutions in the global arena. A descriptive analysis of these data/information has been made for identifying the potential cues for the revival of the Microfinance sector from economic perspectives. Further, evidential cases on perceiving emotive clues have been captured towards promoting a participatory preventive governance system by the Microfinance clients. Based on these data, suggestions have been made.

\section{LITERATURE REVIEW}

For the said purpose of the paper, the literature review is done for capturing the secondary data/information broadly covering three areas viz., the status of the microfinance sector in the supply side, the magnitude of victimization of MFI clients in the demand side and the need for participatory governance approach for challenging the COVID-19 impact. 
An Imperative Need for A New Social Order in Microfinance Community - Towards Ushering in A Resilient Eco-System in The Battle Against Corona Pandemic

\section{SUPPLY SIDE}

The MFI Status-Global Scenario

A global scenario on the prevailing situation in the MF industry has been portrayed using the data from the FinDev. Blog (20 May 2020) and the same is descriptively presented region-wise below:

\subsection{ASIA}

An ongoing review of Indonesian Microfinance institutions points out the challenges that are facing the MFIs in the period of the pandemic. Administrative measures may have affected customer conduct as practically $50 \%$ of the establishments studied said they are managing clients who will not pay their advances even though they have the way to do as such. On account of Nepal, the banks have digitized settlement preparing after the lockdown started on $24 \mathrm{March}$, as the national bank endeavors to advance electronic exchanges the nation over. The Indian government has declared the second tranche of financial help measures to help transients, road sellers, little dealers, and ranchers. Little advances of up to USD 660 gave under the Micro Units Development and Refinance Agency (MUDRA) will be qualified for a 2 percent intrigue aid, under a plan which expects to profit 30 million individuals. The legislature likewise opened a USD 660 million exceptional credit office for road sellers, under which a merchant can get introductory stirring capital up to $\$ 132$. The program intends to benefit 5 million workers. In the case of Bangladesh, the legislature is giving direct money help to 5 million families influenced by a coronavirus crisis. The USD 30 exchange is viewed as a present for the Muslim festival of Eid and will be conveyed through portable banking to every family.

\subsection{AFRICA}

Ghana turns into the world's first nation to Digital Financial Services (DFS) arrangement. The administration plans to use DFS in its COVID-19 reaction. In Nigeria, banks shut during the lockdown, however, numerous operators kept on offering financial services utilizing versatile instalment applications. In Rwanda, where the National Bank of Rwanda initiated a brief arrangement of zero charges for versatile cash and cashless exchanges for a quarter of a year, more individuals are changing to portable cash moves. With money transfer agencies shut and settlements expected to drop, some money-related specialist organizations in West Africa are restricting the utilization of cash.in Brazzaville, the Republic of Congo, a blend of lost earnings and higher food costs because of upset food flexibly ties has prompted an expansion in hunger. In South Africa, packs convey food in poor neighborhoods during the lockdown. Exercises from past emergencies can assist with reinforcing food flexibly chains. On account of Nigeria, The customers of MFIs are hard hit by the lockdown proportions of their legislatures and their business that has been supported by MFIs is practically going into elimination. MFIs themselves are prohibited by most Central Banks of their nation (at any rate in Nigeria) from any type of buffer that could help in renegotiating their customers at an exceptionally low-financing cost. It is trusted that MFIs that are accomplices to individuals from this Coalition profit by this bailout plan. Inability to accomplish this will continue expanding the neediness and increasingly miniaturized scale customers will fall underneath the destitution line and achievements previously accomplished in Financial Inclusion will relapse (Ogunleye, 2020).

\subsection{LATIN AMERICA AND THE CARIBBEAN}

Brazil rose as the nation with the third-most noteworthy number of affirmed coronavirus cases. About 13.5 million individuals in Brazil live in extraordinary destitution, which is relied upon to increment by up to 9 percent in 2020. Nations in Latin America and the Caribbean have spent a normal of 2.4 percent of GDP on crisis financial bundles, which is less than the worldwide average of 3.7 percent. Peru is the most elevated high-roller (9 percent of its GDP) while Nicaragua has not submitted any spending to stand up to the pandemic. In Colombia, the microcredit part asserts that a parliamentary proposition to expel contrary information from credit department reports could constrain budgetary foundations to fix their loaning and leave more than 3.2 million individuals in the hands of 
advance sharks. The Ecuadorian Government is suggesting a regulation that will entail financial institutions to rebuild customer obligation and lessen loan costs; the microfinance area says the proposition is politically spurred.

\subsection{ARAB WORLD}

The Lebanese Microfinance Association (LMFA) propelled a smaller than usual arrangement of video interviews with financial inclusion specialists on the effect of COVID-19 on MFIs and the job of the division in the recuperation stage. The Jordanian Microfinance Network, Tanmeyah, says the lockdown has offered an approach to informal lending in the nation. As indicated by the most recent Wamda Research Lab report, more than 70 percent of new companies in the Middle East and North Africa have been adversely affected because of the pandemic, while 50 percent have encountered disturbance in financing. Food costs have expanded in many nations in the district. The most noteworthy increments in the price level were evident in Yemen, Lebanon, and Iran where costs of staple nourishments expanded by more than 10 percent since February 2020.

\subsection{COLLECTIVE ENDEAVOUR OF MFI}

Concerning reactions that are taken for challenging the Corona pandemic by the MFIs, the Find Dev. Gateway sees that there is no single activity that can address the impacts of COVID-19 on the lives and jobs of the base of the pyramid (BOP). Aggregate activity is required. Over the recent months, it is noted phenomenal coordination among financial specialists, donors, and other industry on-screen characters all looking to help the BOP and the institutions that aid them. We are building an alliance so these organizations that serve the poor with financial services additionally have a voice in the COVID-19 reaction.

By and large, these institutions and their investees and partners serve over 80 million dynamic clients, 69 percent of whom are ladies. Every one of these institutions has extended their ability to convey financial services particularly in portable and specialist banking - and reinforced their framework through mechanical developments and digital communications, planning to quicken responsible financial inclusion. In particular, the microfinance institutions represented in this alliance work toward the sides of the world that are regularly hardest to reach. The Find Dev. Gateway reported that they all collectively work or support microfinance partners in 23 of the 47 least developing countries.

\section{DEMAND SIDE}

\subsection{THE MAGNITUDE OF VICTIMIZATION IN THE POVERTY SECTOR}

For poor people, the financial impact will be devastating and far more immediate. International organizations estimating a huge impact of the virus on the poverty sector, Oxfam for example estimates that the COVID19 Virus might push around one billion individuals into the poverty circle and the World Food Program also anticipates that the food security of the poor people communities worldwide will be also affected. In addition to them, the United Nations (UN) also predicts that the effect on the world poorest will last for years (Tarazi, 2020). Such a pandemic may act as a formidable development challenge (UNISDR, 2015). Poor people shall lose their income either by illness or through the lack of demand for their products and services as their enterprises come to standstill. The long closure of operations along with severe economic downturn will cause clients defaults on their loans (Abed et al, 2017). The effect of the virus in the developing countries is expected to be greater than the developed countries this is because of the weak available health care system that is identified as ill-equipped that cannot deal with this pandemic. This experience has been learned from the previous Ebola epidemic concluded that the informal, urban and nonagricultural firms were the most affected segments (Bull, 2020).this may indicate the need for financial inclusion as it allows poor people and low-income class to build their assets, mitigate emergencies shocks, illness or injury and make productive investments.it further stimulates the local economic activities by funding micro business that leads to more economic growth (Elzoghbi, 2017). It is emphasized that if poor individuals need to be supported with promicro-financial products and services crucial for establishing their activities, the pro-poor package should cover the potential risks, saving for the future, and building the necessary skills and capabilities (Alshebami et al, 2020). 
An Imperative Need for A New Social Order in Microfinance Community - Towards Ushering in A Resilient Eco-System in The Battle Against Corona Pandemic

\subsection{MICROFINANCE CLIENTS - THE MAGNITUDE}

Presently, the whole world is suffering from the so-called COVID-19 pandemic that has almost paralyzed the entire world and heavily affected the poor segment of it. Poor people are affiliated often to the microfinance sector that had a combined portfolio of about $\$ 124$ billion in outstanding loans and about $\$ 80$ billion in saving (Greta Bull, 2020). There are about 139.9 million individual borrowers who have received supports from the services of MFIs compared to merely 98 million who received similar benefits in 2009. Of these 139.9 million borrowers, $80 \%$ are women and 65\% are rural borrowers (Microfinance Barometer, 2019). The poor people have been largely affected by this pandemic because its impact has gone beyond their immediate health needs and it has prevented them from meeting their most necessities and lead to more acute on the economic well-being (Beinker, 2020). This reminds us of the West Africa Ebola crises that took place in the year 2014 which had an economic impact of more than \$2.8 billion as per the estimates of the World Bank (Abed et al, 2017).

\subsection{FINANCIAL STRESS}

Both poor individuals (borrowers) and MFIs are affected heavily from the continuous lockdown, as MFIs operate for the poor low-income people, it is expected to be affected either positively or negatively in response to them. Once microfinance borrowers default from repayment, this leads to more Non-performing Asset (NPA) making MFIs unable to continue operating which ultimately results in their bankruptcy. This phenomenon causes buoyancy in the level of financial stress to both the lender and borrowers. In India for example, The Credit Rating Agency (ICRA) reported that the Covid19 shall strain the assets quality portfolio and liquidity of microfinance institutions (MFIs) and will also affect their capability of repaying interest on borrowings (Singh, 2020). Microfinance economics is very sensitive hence it requires a high repayment rate. Any a slip in the repayment rates from $95 \%$ to $85 \%$ may render MFIs insolvent in just one year (Bull, 2020). MFIs need to protect themselves with insurance to meet any defaulting or emergencies. Even remittances transferred by borrowers will diminish meaning remitters will not be able to send them anymore due to the loss of income (Tarazi, 2020).

According to (Rani, 2020), the BFA survey conducted recently in Africa revealed that in most of the small enterprises, the income was down by about $90 \%$ forcing workers to consume their savings and also borrow from friends and families. Living without basic access to nutrition, clean water, housing, food and other necessities in poor communities make hand-washing, maintaining good nutrition and self -quarantines a bit challenging task. This is a challenge because there is around $75 \%$ of the microfinance loans are extended to people residing in rural and semiurban areas (Roy, 2020). Therefore, after any disaster, MFIs could face a major challenge i.e. the liquidity issue which may hinder their sustainability forcing them to take some emergencies accordingly. The experience from the Haiyon demonstrated that the liquidity played a bigger role than capital to such a response (Asian Development Bank and Vision Fund International, 2016). Still, MFIs may have a few strategies to be followed after any disaster such as the provision of repayment holidays, loan forgiveness, compulsory saving, and cash aid in addition to recovery loans. They should also ensure the delivery of accurate information, protective types of equipment, and safety training in addition to spreading awareness about the necessary healthy practices.

\subsection{CO-VULNERABILITY - DIGITAL FRAUDS}

The COVID-19 is not the only enemy for poor people these days, new threats have also been threatening their lives such as the online fraudsters who have been attempting to unfairly benefit from them. In India for example, scammers offer poor households people a free Netflix subscription during the lockdown and send them a link to click on. They also provide fake offers for emergency money. In South Africa also, scammers have been visiting homes to recall banknotes and coins claiming that their money has been contaminated with Coronavirus and offering them receipts for clean cash that is never delivered. It was also reported that criminals have been found calling victims and pretending to be hospital officials informing them that one of their relatives has been admitted to the hospital due to coronavirus infection requesting money for medical treatment (Medine, 2020). This results in losing confidence in digital technology which is considered a very significant tool for communication at the time of the crises and pandemic. Already existing digital divide in the Microfinance sector excluded many poor in the pyramid 
and this kind of online fraud adds fuel to the fire in the agony of the Microfinance sector. Therefore, there is a need for cooperation between governments, MFIs, donors, NGOs and other necessary bodies to ensure the provision of the proper protection guidelines for microfinance clients and how to avoid such fake offers form scammers including the ones claiming the delivery of fake medicine products, such as masks, testing kids and vaccines.

\subsection{FORTIFICATION AGAINST COVID-19}

According to Asian Development Bank's report (ADB)Microfinance Institutions (MFIs) can have seven key areas that help in ensuring resilience according to (ADB, 2016) i.e. secure saving, small loans, enhanced credit life insurance, business assets insurance, crop and livestock insurance, low-cost medical insurance and recovery lending. It further reports that for loans that are exposed to losses through floods, droughts, and storms, MFIs can assist their customers with grace periods, loan restructuring and recovery loans that support their recovery from such shocks. Poor people could be majorly affected due to the non-availability of a proper insurance scheme in addition to the mismatch between demand and supply of credit post to the crises. However, it is necessary to note that when planning to provide recovery measures such as recovery loans for borrowers there is a need to attempt to encourage borrowers to repay the amounts borrowed previously as well as make sure that they will not be affected by this request. Offering random cash as a subsidy or charity without having clarity may put more oil on the fire if they are not carefully restructured.

The experience of the Bangladesh Rural Advancement Committee's (BRAC) MFI during the Ebola crises a few years back revealed that all clients were informed that they should have good standing accounts to ensure receiving new fresh loans. Liquidity is a very important tool for fighting the Coronavirus to ensure the business continuity and unfortunately, most of the MFIs do not have access to emerging liquidity from other financial institutions such as the central banks as they are not categorized as commercial banks. There is also a need to have professional staff with high capacity empowered to respond to unexpected situations. According to them a few of the very important activities that have to be carried by the MFIs during the lockdown can be summarized as A) having a common objective of the protection of the employees B) the provision of the necessary training and activities that can be carried out during the lockdown period C) involving employees in more beneficial activities and initiatives to increase their confidence and trust D) the establishment of effective communication with staff and clients E) the management of financial relief to clients F) enhancing the process of credit approval J) the provision of clear guidelines for their clients $\mathrm{M}$ ) ensuring the availability of MFIs insurance for both clients and MFIs and finally making sure to digitalize the maximum products and services offered by the MFIs in addition to setting up emergency plans.

Since the Coronavirus is still in its primary stage and it is not known yet when it will be finished, it is too early to anticipate how it will impact the financial life of the poor, its period, and its impact on various economic aspects (Tarazi, 2020). There should be cooperation among all microfinance stakeholders i.e. donors, MFIs, Clients, governments, private sector, NGOs, and other parties to organize efforts that ensure the continuity of the operation of MFIs in the market. According to the Microfinance Coalition (2020), there is no individual action that can address the effect of Covid-19 on the livelihood of the base of the Pyramid. Donors for example should develop long and short terms responses market stability. The careful intervention of various parties with this pandemic may lead in the future to more financial inclusion, meaning the conversion of the crises into an opportunity to include more people in the financial system. By coordinating with governments' agencies, municipal authorities, and donors, the MFIs are the best position to be a strong partner in local land even national responses (Goldberg, 2008). Governments such as Peru and the Philippines have started responding to the pandemic by maximizing the social safety net payment. Around 60 countries have also increased the scaling up of social protection through one time payments and increasing the current programs or introducing the new ones. The issue with Covid19 is that it is not a local challenge, it a worldwide problem hence its effect resulted in the lockdown which impacted the retails, agriculture, manufacturing, and almost all sectors. However, governments should be very careful while dealing with such crises and while focusing only on the protection of borrowers, it should note that while imposing the MFIs payment reschedule they may contribute indirectly to the liquidity crunch of the MFIs. It is expected to have a huge effect on the microfinance sector worldwide, the study of Mangowal et al (2020) revealed that the liquidity arrears and management morale as the most significant challenges facing the MFIs. It further highlighted the difficulty in conducting collections, having active communications with clients, reduction in the clients' income, the need for 
An Imperative Need for A New Social Order in Microfinance Community - Towards Ushering in A Resilient Eco-System in The Battle Against Corona Pandemic

liquidity support, proper supportive, strict policies to end pandemic, maintain access during social distancing period, provision of the relevant information regarding the impact of the pandemic as challenges for the microfinance sector.

\subsection{CULTURAL BELIEFS AND BEHAVIORAL PRACTICES- EBOLA CASE - WEST AFRICA}

In the demand side apart from the economic perspectives of the corona pandemic, the cultural factors that decide the societal relationship with the pandemic assume importance from social anthropological orientation. In this regard, the World Health Organization has brought out a report vividly on the actors that contributed to the undetected spread of the Ebola virus and impeded rapid containment WHO (2015). As indicated by the report, highrisk behavior in the three nations have been like what has been seen during past Ebola episodes in central Africa, with adherence to tribal memorial service and entombment customs singled out as fuelling enormous blasts of new cases. Clinical anthropologists have, nonetheless, noticed that memorial service and entombment rehearses in West Africa are incredibly high-chance. Information accessible in August, as revealed by Guinea's Ministry of Health, showed that $60 \%$ of cases in that nation could be connected to conventional entombment and memorial service rehearses. In November, WHO staff in Sierra Leone assessed that $80 \%$ of cases in that nation were connected to these practices. In Liberia and Sierra Leone, where internment rituals are fortified by a few mystery social orders, a few grievers wash in or bless others with flush water from the washing of cadavers. Understudies of socially prominent members of these secret societies have been known to sleep near a highly infectious corpse for several nights, believing that doing so allows the transfer of powers.

Ebola has gone after another profound situated social quality sympathy. In West Africa, the infection spread through the systems that predicament social orders together in a culture that burdens empathetic consideration for the evil and stately consideration for their bodies on the off chance that they bite the dust. A few specialists are thought to have become tainted when they hurried, unprotected, to help patients who fallen in lounge areas or on the grounds outside an emergency clinic. As a few specialists have noted, when specialized intercessions cross purposes with dug in social practices, culture consistently wins. Control endeavors must work inside the way of life, not against it.

\subsection{RELIANCE ON TRADITIONAL HEALERS}

The traditional healers have a very old and long history of Africa not just now, it was even before to the pandemic outbreaks. The existence of poor access to government-run health facilities made care by traditional healers or selfmedication through pharmacies the preferred health care option for many, particularly the poor ones. Many cases have been traced to contact with traditional healers or herbalists or attendance at their funerals. After the outbreaks began, the high casualty rate promoted the observation that hospitals were places of contagion and death, additional reinforcing the need for compliance with the recommendation to look for early medical attention. Besides, numerous treatment offices, taken cover behind high fences and now and again hung with spiked metal, looked more like detainment facilities than places for medicinal services and mending.

\subsection{COMMUNITY RESISTANCE, FEAR \& MISCONCEPTION}

The effort to control in many countries has been refused by the community due to many reasons. Major ones of them include the fear and misperceptions about an unfamiliar disease that have been well documented by medical anthropologists, who have also addressed the reasons why many rejected to believe that Ebola was actual. On the other end in the corona case of Chennai city in India, it is reported in news media (Thinamalar, 2020) that due to mind upset two corona affected committed suicide and about 10 such cases absconded from the hospital where there were admitted.

\subsection{PARTICIPATORY GOVERNANCE IN HEALTH CARE SYSTEM}

Participating governance attempts to deepen citizen involvement in the governmental process by assessing the assumptions and practices of the traditional view that generally limit the realization of a genuine participatory 
democracy (Fisher, 2012). The character of the novel Coronavirus is its transformation from human to human. Great wash and waste administration rehearses, that are reliably applied, fill in as obstructions to the human-to-human transmission of the COVID-19 infection in homes, networks, social insurance offices, schools, and other open spaces. Safely managed wash services are also critical during the recovery phase of a disease outbreak to mitigate secondary impacts on community livelihoods and wellbeing. (WHO, 2017) and therefore the participation in preventive governance by individual humans and the community people to coordinate with the public authorities has become an inevitable one towards challenging the said crisis. The following information on socially appropriate strategies through the participatory approach experienced elsewhere on the planet is analyzed. This perspective of community involvement is designed in line with the recommendation of the World Health Organization (WHO). Among the ten recommendations made in the WHO report, the one that considered important includes community resilience strengthening, develop WHO SSI guidelines and develop tools and models to apply cultural, historical and political knowledge to health emergencies, support long-term social science research that feeds directly into a platform capable of assisting a rapid response (WHO,2017).

In this regard, ICSSR-ICMR Committee Report among others emphasized the need to replace the existing model of health care with an alternative one that is integrated, primitive, preventive, and curative services and is community-based, participatory, decentralized, and democratic, merit attention more from suicidal science perspectives (NayariK.R., 2012). Further in such community involvement, individual measures merit attention in local preventive measures. Here the importance of effectiveness in individual participation in the battle against pandemic assumes significance as highlighted in the European center for disease prevention and control (second update) on considerations relating to social distancing measures in response to COVID-19. The update indicates the measures for social distancing and exit strategies. Also, it cautions that the potential delay of the peak is likely to depend on how early the measures are taken in the context of the local epidemiological situation. Besides, the layering of multiple measures is likely to increase the composite effectiveness of individual measures (ECDC, 2020). The research paper from the Training and Research Support Centre, Zimbabwe has inspected the characteristics of social and governance systems that support vertical equity in health and their existing applications within health systems. It recommends measures and mechanisms that essential to be included or strengthened in health systems if we are to boost the association between citizens and state towards enhancing vertical equity. Finally, it proposes further effort and works towards strengthening the social dimensions of equity in health. (Loewenson, 2000).

The role of social capital assumes in the discussion on participatory governance as it represents the collectives of the people in the last mile .In this regard, the research paper of (Somayyeh et al, 2017) revealed that there was a significant association between social capital and its components namely trust, sense of belonging, social participation. Furthermore, there was a significant relationship between social support and its dimensions i.e. emotional, instrumental, and informational with general health. At the individual level another factor viz., behavioral matters as it influences the effectiveness in the participation due to incompatibility of the value system. "Be it poor or non-poor community, it is not uncommon to witness a conflicting tendency between the internal value system (individual) and external value system (in the universe with more influence of latter on the former society/market institution) (Rengarajan, 2013). Another dimension of individual human behavior as pointed out by AmartyaSen is self-interest maximization. Sen argues that 'the self-interest view of rationality' involves inter alia a firm rejection of 'ethics-related view of motivation' (AmartyaSen, 1987).

From interdisciplinary perspectives, these aspects of the behavioral pattern as discussed above at the individual level would be considered through constructive ethical nurturing of human beings for ensuring the welfare of both self and community at large towards ushering in a conducive societal relation in challenging the COVID-19 crisis collectively. For the said purpose, an indigenous value-based knowledge management system is conceived for effective Information, Education, and Communication (IEC) through social capital at the community level. The appropriation of the application of IEC in the health domain has been indicated by WHO. An operational definition of "IEC" refers to a public health method aiming at changing or reinforcing health-related behaviors in a target audience, concerning a specific problematic and within a pre-defined period, through communication approaches and principles (definition adapted from "Information, Education and Communication - Lessons from the past; perspectives for the future" - WHO, 2014). 
An Imperative Need for A New Social Order in Microfinance Community - Towards Ushering in A Resilient Eco-System in The Battle Against Corona Pandemic

\section{CONCLUSION}

From the descriptive portrayal of the status of the microfinance sector in the framework of the Corona pandemic, it is seen that the novel coronavirus spread has immensely impacted in terms of loss of business and income to the players in both supply and demand sides in the microfinance sector. The following are some of the crucial conclusions on the status of the microfinance sector distinctly for the supply and demand side.

\section{Supply-Side}

First, it is amply evident that there is a shortage of liquidity for the MFIs in the Corona pandemic period while MFIs are rushing to revive the microfinance sector through more pumping microcredit to the poor. For the said purpose these institutions collectively constitute an essential "last mile" network, to reach into communities in which people may otherwise miss out on support because of imperfect access, literacy, infrastructure, or technology connections. Combined, these elements place microfinance as an important device to not only mitigate the economic impact of the crisis but also to quicken recovery from it.

Second, these MFIs are equally concerned with the recovery of past debt lent to MFIs clients since millions of their clients have lost their livelihood financed by the MFIs due to the implementation of lockdown measures implemented by the respective government to protect the viral spread.

Third, although digital technology has facilitated money transfer and communication at times of crisis and pandemic directly to the poor clients, digital frauds as reported in South Africa results in losing confidence in digital technology. From demographic perspective already existing digital divide in microfinance sector indicates the exclusion of many poor in the pyramid (Fig. 1) and this kind of online fraud which is prevalent in different forms and magnitude in many regions in the globe add fuel to the fire in the agony of microfinance sector hindering the process of revival of microfinance sector from the COVID-19 impact.

Fourth, it is encouraging to observe arrangements for refinancing facility from Apex institutions like Reserve Bank of India (RBI) and National Bank for Agriculture and Rural Development (NABARD) as in India to MFIs through Non-Banking Financial Institutions (NBFC) and the commercial bank as it would help the revival of livelihood activities of the poor clients.

The last, the role of microinsurance which has not received due attention in the microfinance sector assumes a significant presence in the context of the impact of Corona devastating the livelihood activities in the poverty sector which could have been protected by inclusive insurance approach. But the non-availability of proper insurance packages to the poor (Alshebami et al, 2020) has affected much besides mismatch between supply and demand of credit in this sector as pointed by the Asian Development bank.

\section{Demand-Side}

In the first, for the poor people in the sector, the financial impact will be devastating and pushing them to the bottom of the pyramid (fig. 1). It is predicted that the pandemic effect on the World's poorest will last for years.

Second, the effect of the virus in the developing countries is expected to be greater than the developed countries this is because of the presence of the feeble health care system that is identified as ill-equipped that cannot deal with this pandemic. This experience has been learned from the previous Ebola epidemic concluded that the informal, urban, and non-agricultural firms were the most affected segments. This situation indicates the requirement of a microfinance package (Alshebami, 2017,2014,2015) beside micro-credit alone for meeting the diversified needs of the poor such as meeting immediate consumption needs for survival building income-generating assists, mitigating emergencies shocks illness, etc., in the demand side for challenging the Corona crisis. The conventional way of mere microcredit lending alone is harmful as the poor clients spend for meeting immediate consumption needs and repayment of earlier dues without making any fresh investment for new income generation during corona periods as this phenomenon retorts affecting a sustainable resurgence of this sector.

Third both poor individuals (borrowers) and MFIs are affected heavily from the continuous lockdown, as MFIs operate for the poor low-income people, it is expected to be affected either positively or negatively in response to them. Once microfinance borrowers default from repayment, this leads to more NPAs making MFIs unable to continue operating which ultimately results in their bankruptcy. This phenomenon causes buoyancy in the level of financial stress to both the lender and borrowers in the MF market domain. Further, this financial stress added with psychological fear over the corona pandemic affects the resilient ecosystem for the revival of the MF sector. 
Last not the least one in the demand side pertains to the cultural factors and the human behavior pattern in the given demographic that are influencing the societal relationship with the epidemic at community level regardless of the status of the clients be it poor and non-poor (Rengarajan, 2013). As highlighted in the WHO report, the anxiety and misperceptions about an inexperienced disease have been well documented by medical anthropologists, who have also addressed the details of why many people refused to believe that Ebola was real. As several specialists have noted, when technical interventions cross purposes with entrenched cultural practices, culture always wins. Control exertions must work within the culture, not against it. Such a phenomenon, embedded in respective indigenous socio-cultural values in different regions/countries holds good for the corona pandemic also globally.

Another dimension of the cultural factors at an individual level is the behavioral pattern of the clients. From interdisciplinary perspectives, these aspects of the behavioral pattern at the individual level assume significance for participating in preventive governance of Corona spread through the mode of constructive ethical nurturing of human beings. This would help to ensure the welfare of both self and community at large towards ushering in a conducive societal relation in challenging the COVID-19 crisis collectively. This factor calls for a participatory approach which is discussed below. In fine, taking into cognizance of the various interdisciplinary factors that drive the COVID-19 pandemic, it is concluded that microfinance actors need to consider the following message.

The economic restoration bundle should not confine with a fresh dose of microcredit and recovery collectively or individually in the microfinance sector without synchronizing a social-oriented package in the financial set. These integrated inputs are essential for fostering health care awareness and for adherence to mandatory norms of preventive measures namely social distancing, face mask, hand washes by the individual poor customers in their livelihood activities in the last mile. Any conjecture on this factor is risky. The latter which ensures the basic survival of the clients from the Corona pandemic, should proceed with the former one or integrated simultaneously with it to create a resilient ecosystem from interdisciplinary perspectives. Otherwise, another microfinance crisis is imminent (Rengarajan, 2020).

\section{PARTICIPATION}

It is revealed from the literature study that the strategic need for Participation of people in the battle against novel coronavirus, having a particular character of its transformation from human to human, has become an inevitable one for preventing its spread vitally at the individual household level since previous experiments with the involvement of people succeeded in achieving similar goal in the health care cases like Ebola epidemic. In such a process the active involvement of social capital (Self Help Groups- Asia, Savings \&credit associations-Africa, etc.) has potential in nudging accountable behavior of the human for adherence to preventive health care norms at the society level. By this way, if community themselves takes responsibility for undertaking the said preventive measures, it would certainly ensure a candid circuit breaker of the virus infection with the least cost and sustained resilience in the bio-war thereby such a system enables a drastic reduction in public expenditures in the health sector and better utilization of health workers and researchers, more towards curative oriented tasks in this pandemic.

\section{SUGGESTIONS}

Taking into cognizance of its constraints and compulsion as observed above on the status scenario in the microfinance arena following suggestions are made. Here it is emphasized, that articulation of a well-balanced stimulus package in the corona framework, merit the attention of the concerned for administering these inputs sequentially for challenging health vulnerability first and subsequently economic deprivations. Such a contextual prudential strategy in the microfinance sector would help to minimize the human cost first and also paving the path of structural reforms subsequently during the corona period.

\section{TOWARDS CHALLENGING HEALTH VULNERABILITY}

1) The first strand in the crisis management is to ensure on priority basis that human cost of COVID-19 crisis in microfinance sector is minimized especially for those in the bottom of the pyramid who is the victim of both health vulnerability and economic deprivation. 
2) When the survival of human being that includes the actors in both supply and demand sides in microfinance platform, has been recognized as a prime target for immediate protection, participatory approach as experimented successfully in health care governance elsewhere in the planet with the involvement of local people and social capital in the last mile needs to be articulated thereby entrusting the responsibility of preventive measures against the coronavirus spread at household and community level. In such process, this local social capital (SHG. Savings \& credit associations and the like) need to be empowered to supplement their services with that of health care governance executed by the public health departments of the respective $\mathrm{p}$ government as it ensures effective outreach to the target population on one hand and enables cost reduction in public health budget given the magnitude of pandemic spread unabated in all the parts of the world on the other.

3) Candid participatory governance cannot emerge in vacuum due to the presence of fragile societal relationships in the battle against the coronavirus. This factor demands ethical nurturing of the people and society by NGO/VO principally supplemented by the public and private agencies in the last mile.

4) 4. For the said purpose of nurturing, dissemination of information related to COVID-19 needs to be pronounced through a mode that is embedded in an indigenous value-based knowledge management system conceived for effective Information, Education and Communication (IEC) as designed by WHO.

5) Taking cues from the lessons from the observations made on cultural beliefs and behavioral practicesEbola case - West Africa, control efforts as suggested above $3 \& 4$ must work within the culture, not against it. In such cases the role of traditional healers/local religious profit/ palmist/. Fortune-teller (A common phenomenon in Africa and Asia region) needs to be recognized for removing the stigma and misperceptions about an unfamiliar disease corona.

\section{TOWARDS STIMULATING ECONOMIC RESURGENCE}

\subsection{THE LIQUIDITY CRUNCH}

In the prevailing unabated corona spread globally, the microfinance sector has been paralyzed by severe liquidity crunch due to frequent lockdown measures in varying degrees in many countries. This challenge of liquidity needs to be prudently diagnosed on the uniqueness of complexities of the corona induced liquidity in general. "A liquidity crisis is a simultaneous intensification in demand and a reduction in the supply of liquidity across many financial institutions or other businesses. Liquidity crises can be triggered by large, negative economic shocks or by normal cyclical changes in the economy (Google, 2019). Unlike the system-oriented micro-financial crisis in 2010-2011 caused by factors like unethical competition in credit sanction, multiple financing, overindebtedness of the poor clients, poor recovery, coercive recovery, etc. (Rengarajan, 2013) the peculiarity of the current corona impacted microfinance poses a formidable challenge in a liquidity crisis. Contextually both the actors, being human beings in both demand and supply side face a greater life survival risk in the process of undertaking any livelihood activities regardless of the flow of liquidity in the sector. Any human causality either in the supply side or demand side in the market at the field level is harmful destroying the business relationship socially and financially as well. It is therefore prudential one to ensure $100 \%$ preventive measures against COVID-19, are adhered to by all the players responsibly in the Microfinance industry. With the above indispensable rider following strategies may be followed towards attaining socially justifiable liquid management from human wellness perspectives.

\section{COLLECTIVE ACTION OF MFIS}

Towards saving the lives of millions of livelihoods during the post-pandemic world, these institutions cooperatively constitute a crucial "last mile" network because of imperfect access, literacy, infrastructure, or technology connections (where digital experience is limited and novel). Combined, these components position microfinance as an acute instrument to not only mitigate the economic crisis but also to quicken retrieval of MFI from it. 


\section{REFINANCING BY APEX BANK}

The apex institutions acting as a monetary authority in the financial sector in the respective government need to consider refinancing facility to MFIs through institutional modes like NBFC and, the commercial banks (RBI /NABARD in India) with the mandatory norms for both health and financial governance at institutional and client household level market level.

\section{SOCIAL WELFARE LIKED INTEGRATED MICROFINANCE PRODUCTS}

Provision of any sequestered credit product either through digital or non-digital mode in poverty sector during the period of unabated spread of coronavirus, will be spent on only consumption purposes (for meeting past \&current) \& and repaying the accrued past debt due to unpaid rent /wage linked to livelihood management, etc. Eventually, in that case, financial stress in terms of over-indebtedness to poor clients" household in the demand side and accrual of Nonperforming assets to MFIs in the supply side would further intensify the magnitude of the crisis in the microfinance sector. It is, therefore, suggested an integrated social welfare-oriented package consisting of both financial and non-financial products is to be designed and provision of the financial package in haste needs to be postponed till the end game of coronavirus spread in different countries.

\section{PARTICIPATORY APPROACH}

In the context of persisting COVID-19 spread leading to more spread and human mortality despite the implementation of various preventive and curative measures by the respective governments in many densely populated countries like India, there appears to be some communication gap in outreaching the poor people in the last mile. Therefore, it has become an imperative one for nurturing the people more ethically for taking ownership of the problems of pandemic and actively participating in the preventive governance system. The past experiments reveal the development potential of social capital for the said purpose. In this context following two strategies are suggested to create a sustainable resilience ecosystem for prudential micro-financing in the post corona period.

\section{MFIS MORE AS NGO/VO}

There is a need to involve more of their groups like SHG and savings \& credit association in the preventive governance system at the community level and nudge them for taking responsibility for preventive measures at the village level regardless of clients or non-clients. As most MFIs in countries like India, Bangladesh Nepal have been erstwhile NGOs, performing the social-oriented said task is not difficult in the field. The best model practiced by the Bangladesh Rural Advancement Development committee could be emulated with more concentration of activities concerned with COVID-19 pandemic until the crisis is over without much performing financial activities.

\section{MFI'S COORDINATED WORK WITH LOCAL VIPS}

As similar to the collective and coordinate work for fundraising to challenge the liquidity crunch in this sector, MFIs need to create a resilient ecosystem for running their business sustainably with the safety of clients' survival in the pandemic period. For this task, they have to coordinate with the public officials to synchronize their health cure activities through the collectives of microfinance beneficiaries like SHG. Further given diversified demographic and religious \&culture system in the last mile which is a common phenomenon in Asia and Africa regions, the local VIPs, and religious leaders who greatly influence the culture and behavior of the local community need to be associated with the preventive care governance to challenge the coronavirus at community level regardless of microfinance clients or non-clients. Imperatively the spirit of WHO viz., "No one is safe until everyone safe" is to be maintained by all the players in the microfinance arena for creating a resilient microfinance industry from the corona pandemic. 


\section{MFIS - KNOWLEDGE MANAGEMENT}

An indigenous value-based knowledge management system is to be conceived for the development of an effective information package as outlined by WHO.MFI and NGOs in consultation with the local VIPs /knowledgeable persons may prepare the following works for effective disseminating the health care information required for the prevention of coronavirus spread. These kinds of socially oriented activities should become an integral part of microfinance management work at least during the corona period in microfinance industries.

Table 1: Knowledge Management

\begin{tabular}{|c|c|}
\hline Information & $\begin{array}{l}\text { Information specifically needed for preventive governance against corona spread and } \\
\text { translated into the local language. Comparison with traditional local norms adopted for } \\
\text { challenging the similar pandemic earlier as this would help to reinforce a set of behavior to } \\
\text { face the corona pandemic fearlessly and confidently. }\end{array}$ \\
\hline $\begin{array}{l}\text { Dissemination } \\
\text { (modes) }\end{array}$ & $\begin{array}{l}\text { MFI, NGO along with public health workers for sharing objective oriented explicit } \\
\text { knowledge through the SPL campaign to the people at the village level. } \\
\text { MFI-NGO along with local social capital. (SHG/Traditional/religious health healer/. for } \\
\text { sharing the community value-based implicit knowledge through pedagogy model } \\
\text { (experienced person recovered from Corona attack to other people to convince and remove } \\
\text { trauma psychologically. }\end{array}$ \\
\hline $\begin{array}{l}\text { Communication } \\
\text { (modes) }\end{array}$ & $\begin{array}{c}\text { Arrangement with local community radio and other mass media. Local cinema/ Drama } \\
\text { theatre. } \\
\text { Cultural program through street theatre, folk songs village koothu (drama) at places near } \\
\text { the local temple, and Shandy (market) places. }\end{array}$ \\
\hline
\end{tabular}

Source: Compiled by the researchers

In peroration, it is reiterated that during the corona period with the dubious end, MFI needs to concentrate on implementing social \& health-oriented action programs in their command area collectively or individually as suggested in the paper. These social-oriented activities through well nudged social capital would facilitate ushering in a new social order with a resilient ecosystem that helps in ensuring sustainable wellness of the MF actors on one hand and also facilitates in enabling economic resurgence for MFI and MF clients as well from income deprivation caused by the virus linked lockdown on the other hand.

The limitation of the paper is the use of secondary data on the implications of Corona pandemic suggestions which are only in predictive nature since the end game of this crisis remains dubious. The findings of the paper should be taken no more than an interim assessment.

\section{SOURCES OF FUNDING}

This research received no specific grant from any funding agency in the public, commercial, or not-for-profit sectors.

\section{CONFLICT OF INTEREST}

The author have declared that no competing interests exist.

\section{ACKNOWLEDGMENT}

None. 


\section{REFERENCES}

[1] Abed, S., Diallo, A., Dubitsky, R., \& Karmaker, T. (July 2017). Financial Inclusion and Resilience: How BRAC's Microfinance Program Recovered from the West Africa Ebola Crisis. Liberia; Sierra Leone: BRAC.

[2] Alshebami, A. S. (2017). The Role of Microfinance in Mitigating Poverty and Unemployment in Yemen. India, Maharashtra, Nanded: SRTM University (Ph.D. thesis).

[3] Alshebami, A. S., Morsi, S. A., Raza, M., \& Aziz, A. (2020). Exploring the Potential of Microinsurance for Challenging the Vulnerabilities In Poverty Sector of Yemen: (An Empirical Study From Demand-Side Perspectives). International Journal of Disaster Recovery and Business Continuity, 1288-1302, Vol. 11, No. 1, (2020).

[4] Alshebami, A. S., \& Khandare, D. M. (2014). Microfinance in Yemen "Challenges and Opportunities “. International Journal in Management and Social Science, 2(12). Retrieved from http://www.ijmr.net.in

[5] Alshebami, A. S., \& Khandare, D. M. (2015a). Islamic Microfinance Industry in Yemen "Challenges and Opportunities." International Journal of Social Work, 2(2). https://doi.org/10.5296/URL

[6] Adebimpe Esther Ogunleye (2020) COVID-19 Comment in Threatens the Microfinance Sector and the Livelihoods of Those We Serve: Building a Coalition for Collective Action Fin Dev Gateway blog A program of CGAP World Bankhttps://www.findevgateway.org/blog/2020/05/covid-19-threatens-microfinance-sectorand-livelihoods-those-we-

servebuilding?utm_source=ENGLISH+May_27_2020\&utm_campaign=English+28+April+2020+gateway+exc hange\&utm_medium=email.

[7] Amartya Sen. (1987). Self-interest and rational behavior ethics and economics at Oxford University presser 1987. p15.

[8] Bach M, Jordan S, Hartung S, Santos-Hövener C, Wright MT (2017). Participatory epidemiology: the contribution of participatory research to epidemiology Med Central Journal National Institute of Health's National library of medicine https://www.ncbi.nlm.nih.gov/pubmed/28203262.

[9] Barometer, M. (2019 -10 edition). Microfinance Barometer,10 YEARS ALREADY!, A LOOK BACK AT THE TRENDS IN MICROFINANCE.

[10] Beinker, N., \& Shorey, B. (2020, 12 May). CGAP. Retrieved from Financial Inclusion and Resilience for FDPs in the Time of COVID-19, Coronavirus (COVID-19): Financial Services in the Global Response: https://www.cgap.org/blog/financial-inclusion-and-resilience-fdps-time-covid-19.

[11] Bull, G., \& Ogden, T. (2020, May 25). COVID-19: How Does Microfinance Weather the Coming Storm? Retrieved from CGAP: https://www.cgap.org/blog/covid-19-how-does-microfinance-weather-coming-storm.

[12] CNBCTV18. (2020, April 15). Retrieved from COVID-19 impact: ICRA sees huge strain on liquidity, the asset quality of microfinance institutions: https://www.cnbctv18.com/economy/covid-19-impact-icra-sees-hugestrain-on-liquidity-asset-quality-of-microfinance-institutions-5694121.htm.

[13] Deshpande, R., Kibe, J., \& Kaaria, L. (2020, April 15). CGAP. Retrieved from COVID-19 Exposes Risks and Opportunities in Kenya's Gig Economy,Coronavirus (COVID-19): Financial Services in the Global Response: https://www.cgap.org/blog/covid-19-exposes-risks-and-opportunities-kenyas-gig-economy.

[14] El-Zoghbi, M., Chehade, N., McConaghy, P., \& Soursourian, M. (No. 12, April 2017). The Role of Financial Services in Humanitarian Crises. CGAP and Its partners.

[15] Goldberg, M., \& Varada, S. (December 2008, NO.8). Microfinance and Disasters Preparing for the Worst. The World Bank, Department of International Development (DFID).

[16] International, A. D. (2016). DISASTER-RESILIENT MICROFINANCE: LEARNING FROM COMMUNITIES AFFECTED BY TYPHOON HAIYAN. Asian Development Bank and Vision Fund International.

[17] K.Mangowal, C. (2020). IMPACT OF COVID-19 TO MFIs IN INDONESIA: A RAPID ASSESSMENT. Indonesia: RISE (Research and Training).

[18] Medine, D. (2020, April 09). CGAP. Retrieved from Financial Scams Rise as Coronavirus Hits Developing Countries, Coronavirus (COVID-19): Financial Services in the Global Response: 2020.

[19] Roy, S. (2020, March 21). BusinessLine. Retrieved from Money and Banking: Covid-19 is no threat to the microfinance industry; sees no impact on loan disbursement, collection: https://www.thehindubusinessline.com/money-and-banking/covid-19-no-threat-to-microfinanceindustry/article31120068.ece. 
An Imperative Need for A New Social Order in Microfinance Community - Towards Ushering in A Resilient Eco-System in The Battle Against Corona Pandemic

[20] Tarazi, M. (2020, April 12). What's a Donor to Do? The Financial Impact of COVID-19 on the Poor, CGAP Leadership Essay Series. Retrieved from Consultative Group to Assist the Poor (CGAP): https://www.cgap.org/blog/whats-donor-do-financial-impact-coronavirus-poor.

[21] ECDC (2020). European Centre for Disease Prevention and Control (ECDC) Second updatehttps://www.ecdc.europa.eu/sites/default/files/documents/ECDC\%20International\%20Relations\% 20Policy\%202020-FINAL_1.pdf.

[22] FinDev Blog (2020) COVID-19 Threatens the Microfinance Sector and the Livelihoods of Those We Serve: Building a Coalition for Collective Action. FinDev Weekly Update A program of Consultative Group for Assisting the Poor (CGAP) -World Bank | 14-20 May 2020 Fin Dev Gatewayhttps://www.findevgateway.org/guide/2020/05/covid-19-findev-weekly-update-14-20-may2020.

[23] Frank Fisher (2012) Participatory Governance: From Theory To Practice, Oxford Handbook online scholarly research

reviewshttps://www.oxfordhandbooks.com/view/10.1093/oxfordhb/9780199560530.001.0001/oxfordh b-9780199560530-e-32.

[24] Elsbet Lodenstein, Marjolein Dieleman, Barend Gerretsen, Jacqueline E W Broerse(2016). Health provider responsiveness to social accountability initiatives in low- and middle-income countries: a realist review Health Policy and Planning, Volume 32, Issue 1, February 2017, pp 125-40, https://doi.org/10.1093/heapol/czw089

[25] (Google,2019).https://www.google.com/search?q=liquidity+crunch+meaning\&rlz=1C1CHBD_enIN849IN84 9\&oq=liquidty+criucnh+\&aqs=chrome.1.69i57j0l7.9213j1j4\&sourceid=chrome\&ie=UT.

[26] JyotiBhola, VandanaRevathiVenkateswaran, and Monika Koul(2020).Corona Epidemic in the Indian context: Predictive Mathematical Modelling -Research Group for Theoretical Models in Eco-evolutionary dynamics, Max Planck Institute for Evolutionary Biology, 24306, Germany https://www.medrxiv.org/content/10.1101/2020.04.03.20047175v1.full.pdf.

[27] Krishnan Reddy. G (2020) an effective lockdown India's containment strategy has been successful The Hindu Newspaper dated 17th May 2020.

[28] KiranMazumdar Shaw (2020). How to make India ready for future corona virus-like crises-Economic Times 21st, March, https://economictimes.indiatimes.com/industry/healthcare/biotech/healthcare/armed-withsolid-bio-data/articleshow/74737523.cms?from=mdr.

[29] Ka Yin Leung, Frank Ball, David Sirl, and Tom Britton (2018)."Individual preventive social distancing during an epidemic may have negative population-level outcomes", Journal of Royal Society Interfacehttps://doi.org/10.1098/rsif.2018.0296.

[30] Kiesha et al., (2020). The Lancet Public Health 'The effect of control to reduce social mixing on the outcome of the COVID-19 epidemic in Wuhan, China; A modeling study https://www.ncbi.nlm.nih.gov/pubmed/322206555.

[31] iK.R., (2012). Three decades of ICSSR-ICMR Committee Report and the Re-assertion of Social Determinants of Health. Indian Journal of Medical Research, 2012 Oct; 136(4): 540-543. https://www.ncbi.nlm.nih.gov/pmc/articles/PMC3516019/.

[32] The National academies (2007). Workshop Summary on Ethical and Legal Considerations in Mitigating Pandemic Disease (Institute of Medicine (US) Forum on Microbial Threats. Washington (DC): https://www.ncbi.nlm.nih.gov/books/NBK54167/.

[33] Oscar A. Martínez-Martínez \& Anidelys Rodríguez-Brito (2020). Vulnerability in Health and Social Capital: A Qualitative Analysis by Levels of Marginalization in Mexico International Journal for Equity in Health.https://equityhealthj.biomedcentral.com/articles/10.1186/s12939-020-1138-4.

[34] Thinamalar (2020) National Tamil daily newspaper Chennai dated 30th May 2020https://www.dinamalar.com/news_detail.asp?id=2548404.

[35] Rene Loewenson (2000). Participation and accountability in health systems: The missing factor inequity? Research

Gate.https://www.researchgate.net/publication/237717601_participation_and_accountability_in_health_sy stems_the_missing_factor_in_equity. 
[36] Rajesh Singh and R. Adhikari (2020). Age-structured impact of social distancing on the COVID-19 epidemic in India,

Research

Gatehttps://www.researchgate.net/publication/340209224_agestructured_impact_of_social_distancing_on_ the_COVID19_epidemic_in_India_Updates_at_httpsgithubcomrajeshrinetpyross.

[37] Rengarajan.V. (2013). Incompatibility of value system and human behavior at client level Microfinance Principles and Approaches: Ten Commandments for responsible financing to the poor, Notion Press, India, $p$ 32.

[38] Rengarajan (2013p49-50) MF crisis in countries in Asia and Africa Microfinance Principles and Approaches: Ten Commandments for responsible financing to the poor, Notion Press, India, pp 48-50.

[39] Rengarajan.V, (2020) Comment in Threatens the Microfinance Sector and the Livelihoods of Those We Serve: Building a Coalition for Collective Action Fin Dev Gateway blog A program of CGAP World Bank https://www.findevgateway.org/blog/2020/05/covid-19-threatens-microfinance-sector-and-livelihoodsthose-we-serve-

building?utm_source=ENGLISH+May_27_2020\&utm_campaign=English+28+April+2020+gateway+exchange \&utm_medium=email.

[40] Somayyeh et al 2017 SomayyehKhazaeian, NourossadatKariman, Abbas Ebadi, and MaliheNasiri The impact of social capital and social support on the health of female-headed households: a systematic review Electron Physician. 2017 Dec; 9(12): 6027-6034.Published online 2017 Dec 25. DOI: 10.19082/6027https://europepmc.org/article/med/29560156.

[41] World Health Organisation (2017). Integrating social science interventions in an epidemic, pandemic, and health emergency response report of an Consultationhttps://apps.who.int/iris/bitstream/handle/10665/259933/WHO-WHE-IHM-2018.1-eng.pdf.

[42] WHO (2014). Child Health and Development: Information, Education, and Communication http://www.emro.who.int/child-health/community-information/information/All-Pages.html.

[43] World Bank (2020). "WASH (Water, Sanitation \& Hygiene) and COVID-19" Brief Context.https://www.worldbank.org/en/topic/water/brief/wash-water-sanitation-hygiene-and-covid-19.

[44] World bank (Brief/ Ap,.16 2020) Poverty and Distributional Impacts of COVID-19: Potential Channels of Impact and Mitigating Policies

[45] http://pubdocs.worldbank.org/en/980491587133615932/Poverty-and-distributional-impacts-of-COVID19-and-policy-options.pdf 